\title{
Model Pembelajaran Kooperatif Jigsaw Berbantuan Media Video Meningkatkan Hasil Belajar IPS Siswa Kelas IV Sekolah Dasar
}

\author{
Ni Putu Suryanita $\mathrm{SP}^{1}$, Ni Nyoman Kusmariyatni ${ }^{2}$ (iD) \\ 1,2 Program Studi Pendidikan Guru Sekolah Dasar, Universitas Pendidikan Ganesha, Singaraja, Indonesia \\ *Corresponding author: putusurya2612@gmail.com
}

\begin{abstract}
Abstrak
Kurangnya kemampuan guru untuk menciptakan pembelajaran yang menyenangkan dan disertai dengan media pembelajaran yang menarik. Penelitian ini bertujuan untuk menganalisis model pembelajaran kooperatif tipe Jigsaw berbantuan media video untuk meningkatkan hasil belajar siswa kelas IV sekolah dasar. Jenis penelitian ini adalah penelitian tindakan kelas yang dilaksanakan dalam dua siklus. Setiap siklus terdiri atas tahap perencanaan, pelaksanaan tindakan, observasi dan evaluasi, serta refleksi. Pelaksanaan tindakan tiap siklus adalah tiga kali pertemuan. Subjek penelitian ini adalah siswa kelas IVA yang berjumlah 26 orang. Pengumpulan data dalam penelitian ini dilakukan dengan metode tes. Data dianalisis dengan metode analisis statistik deskriptif. Hasil penelitian menunjukkan pada siklus I rata-rata hasil belajar IPS diperoleh sebesar 80,77 dengan kategori tinggi. Selanjutnya, pada siklus II rata-rata hasil belajar IPS diperoleh sebesar 86,37 dengan kategori tinggi. Berdasarkan perhitungan gain skor, kualitas peningkatan hasil belajar IPS pada siklus I sebesar 0,16 dengan predikat rendah dan siklus II sebesar 0,46 dengan predikat sedang. Berdasarkan hasil penelitian tersebut dapat disimpulkan bahwa penerapan model pembelajaran kooperatif tipe Jigsaw berbantuan media video dapat meningkatkan hasil belajar IPS siswa siswa kelas IV sekolah dasar.
\end{abstract}

Kata kunci: Jigsaw, Hasil Belajar IPS

\section{Abstract}

Lack of teacher ability to create fun learning and be accompanied by interesting learning media. This study aims to analyze the Jigsaw cooperative learning model assisted by video media to improve the learning outcomes of fourth-grade elementary school students. This type of research is classroom action research which is carried out in two cycles. Each cycle consists of stages of planning, implementing actions, observing and evaluating, and reflecting. The implementation of the action in each cycle is three meetings. The subjects of this study were students of class IVA, totaling 26 people. Data collection in this study was carried out by the test method. Data were analyzed by descriptive statistical analysis method. The results showed that in the first cycle the average social studies learning outcomes were 80,77 in the high category. Furthermore, in the second cycle, the average social studies learning outcomes were obtained at 86,37 in the high category. Based on the calculation of the gain score, the quality of improving social studies learning outcomes in the first cycle was 0,16 with a low predicate and the second cycle was 0,46 with a moderate predicate. Based on the results of this study, it can be concluded that the application of the Jigsaw-type cooperative learning model assisted by video media can improve social studies learning outcomes for fourth-grade elementary school students.

Keywords: Jigsaw, Social Studies Learning Outcomes

\section{INTRODUCTION}

Pada jenjang pendidikan sekolah dasar, siswa dibelajarkan sejumlah muatan pelajaran salah satu di antaranya adalah muatan pelajaran Ilmu Pengetahuan Sosial (IPS). Pembelajaran IPS memiliki kedudukan dan fungsi yang sangat penting dalam mempersiapkan dan membentuk individu yang mempunyai potensi, keberanian, dan memahami keberadaan dirinya sendiri dalam berinteraksi dengan lingkungan (Adiwiguna et al., 2016; Maulida et al., 2020; Meiyani et al., 2017; Putra et al., 2017). Melalui pengajaran IPS peserta didik dapat memeroleh pengetahuan, keterampilan, sikap, dan kepekaan untuk menghadapi hidup dengan tantangan-tantangannya. Pembelajaran IPS hendaknya mampu mempersiapkan, membina, dan membentuk kemampuan peserta didik yang menguasai pengetahuan, sikap, nilai, dan kecakapan dasar yang diperlukan bagi kehidupan di masyarakat (Rusmawan, 2013; Sawitri et

$\begin{array}{ll}\text { History: } & \\ \text { Received } & \text { : June 24, } 2018 \\ \text { Revised } & \text { : July 02, } 2018 \\ \text { Accepted } & \text { : April 24, } 2021 \\ \text { Published } & \text { : May 25, } 2021\end{array}$


al., 2018; Sulfemi \& Mayasari, 2019). Dengan demikian, diharapkan pencapaian hasil belajar IPS mencapai kriteria tinggi bahkan sangat tinggi.

Tercapainya tujuan IPS tersebut harus didukung oleh iklim pembelajaran yang kondusif dan menyenangkan karena iklim pembelajaran yang dikembangkan oleh guru mempunyai pengaruh yang sangat besar terhadap keberhasilan dan semangat belajar siswa. Namun, pelaksanaan pembelajaran IPS di sekolah dasar masih mengalami kendala karena terdapat pemikiran siswa pelajaran IPS merupakan pembelajaran yang membosankan dan bersifat hafalan sehingga siswa tidak tertarik pada pelajaran IPS. Kurangnya keterlibatan siswa juga memengaruhi proses pembelajaran. Adanya siswa yang pasif menyebabkan pembelajaran menjadi tidak efektif. Dengan keadaan yang demikian, dianggap guru belum bisa sepenuhnya melaksanakan pembelajaran yang melibatkan siswa secara aktif. Padahal kemampuan siswa terhadap IPS sangatlah penting, karena bekal pengetahuan sosial sangat menunjang pengalaman siswa untuk menghadapi kehidupan di masyarakat nantinya sesuai dengan tujuan pendidikan nasional yaitu menciptakan insan Indonesia cerdas dan kompetitif.

Berdasarkan hasil observasi yang dilakukan di kelas IVA ditemukan bahwa pada pembelajaran IPS terdapat permasalahan diantaranya 1) siswa terlihat tidak antusias dalam mengikuti pembelajaran, 2) keaktifan siswa kurang, 3) terlihat beberapa siswa bercanda, dan tidak mengerjakan tugas-tugas yang diberikan oleh guru, 4) ruang kelas yang sempit dan panas sehingga mengganggu proses pembelajaran. Permasalahan tersebut tentu akan sangat berpengaruh terhadap hasil belajar siswa karena siswa tidak dapat menyerap materi pembelajaran dengan baik. Selain itu, berdasarkan hasil wawancara guru kelas IVA, menyatakan bahwa dalam pembelajaran IPS siswa sangat sulit diajak menghafal, siswa kurang antusias padahala dalam proses pembelajaran sudah dilakukan dengan memberikan beberapa pertanyaan dan didiskusikan oleh siswa. Selain itu, siswa kadang tidak mau bertanya mengenai materi yang diajarkan, pada saat guru menjelaskan masih terdapat beberapa siswa yang tidak fokus dan bercanda bersama temannya. Perilaku-perilaku ini muncul karena pembelajaran di kelas dirasakan tidak menyenangkan.

Hasil observasi dan hasil wawancara tersebut didukung oleh pencatatan dokumen yang didapat di sekolah. Berdasarkan pencatatan dokumen, rata-rata hasil belajar IPS siswa kelas IVA sudah berada di atas Kriteria Ketuntasan Minimal (KKM) yang ditetapkan yaitu 65. Namun, rata-rata hasil belajar IPS siswa Kelas IVA yang bernilai 79,04 tersebut baru mencapai kategori sedang apabila dibandingkan dengan kriteria PAP nasional. Dengan nilai yang demikian, maka sulit untuk mewujudkan tujuan pendidikan nasional yang menghendaki terciptanya insan Indonesia yang cerdas dan kompetitif. Untuk menjadi insan yang cerdas dan juga kompetitif, pencapaian hasil belajar siswa minimal pada kategori tinggi agar nantinya semua siswa dapat bersaing dalam kehidupan masyarakat. Dari 26 siswa, 13 siswa nilainya masih kategori sedang yaitu rentangan 65-79, 12 siswa nilainya kategori tinggi, dan 1 siswa nilainya kategori sangat tinggi. Hal ini berarti 50\% siswa masih di bawah nilai rata-rata kelas dan memiliki kategori sedang. Hal ini sangat memerlukan suatu tindak lanjut.

Permasalahan di atas jika dibiarkan akan berpengaruh buruk terhadap hasil belajar siswa. Agar dapat meningkatkan hasil belajar siswa, maka perlu sebuah usaha perbaikan atau tindakan untuk menindaklanjuti hal tersebut. Salah satu upaya yang dapat dilakukan untuk meningkatkan hasil belajar adalah dengan menggunakan model pembelajaran. Model pembelajaran yang mampu meningkatkan minat siswa dalam mengikuti pembelajaran sehingga materi pembelajaran dapat terserap atau dapat dipahami dengan baik dan dapat meningkatkan hasil belajarnya. Salah satu model pembelajaran yang dapat dijadikan solusi adalah model pembelajaran kooperatif tipe jigsaw.

Model pembelajaran kooperatif tipe jigsaw merupakan salah satu tipe pembelajaran kooperatif yang mendorong siswa aktif dan saling membantu dalam penguasaan materi pelajaran untuk mencapai prestasi yang maksimal (Effendi-Hasibuan et al., 2020; Putri et al., 
2016; Widiana et al., 2015; Zubaidah et al., 2018). Pembelajaran kooperatif tipe jigsaw merupakan salah satu tipe pembelajaran kooperatif yang mendorong siswa aktif dan saling membantu dalam penguasaan materi pelajaran untuk mencapai prestasi yang maksimal. Pada kegiatan ini keterlibatan guru dalam proses belajar mengajar semakin berkurang dalam arti guru menjadi pusat kegiatan kelas. Guru berperan sebagai fasilitator yang mengarahkan dan memotivasi siswa untuk belajar mandiri serta menumbuhkan rasa tanggungjawab. Bertolak dari hal tersebut, maka dalam pemerapan model ini keaktifan siswa sangat dibutuhkan. Siswa dikelompokkan menjadi beberapa kelompok yang beranggotakan 3-5 orang yang terdiri dari kelompok asal dan kelompok ahli. Siswa memiliki banyak kesempatan untuk mengemukakan pendapat, mengolah informasi yang didapat dan dapat meningkatkan komunikasi antar anggota kelompok, memiliki rasa tanggung jawab terhadap keberhasilan kelompoknya dan ketuntasan bagian materi yang dipelajari, serta dapat menyampaikan informasi yang didapat dari kelompok lain. Jadi, dalam penerapan model ini, keaktifan siswa sangat jelas terlihat di dalam kelas. Ssiwa mampu membangun pengetahuannya berdasarkan hasil diskusi dan berbagi informasi antar kelompok, sehingga nantinya akan berdampak pada hasil belajar siswa.

Penerapan model pembelajaran kooperatif tipe jigsaw untuk meningkatkan hasil belajar siswa pada pembelajaran IPS, dapat dibantu dengan menggunakan berbagai macam media, salah satunya adalah media video pembelajaran. Media video pembelajaran merupakan jenis media audio visual yang menyajikan pesan pembelajaran baik yang berisi konsep, prinsip, prosedur, teori aplikasi pengetahuan untuk membantu pemahaman terhadap suatu materi pembelajaran dalam bentuk gambar dan suara (Ponza et al., 2018; Pramana \& Suarjana, 2018; Risky, 2019; Sulfemi, 2019). Media video pembelajaran dapat diartikan sebagai media yang digunakan untuk merangsang pikiran, perasaan dan kemauan siswa untuk belajar melalui penayangan ide atau gagasan, pesan dan informasi secara audio visual (Darihastining et al., 2020; Pramana \& Suarjana, 2018; Risky, 2019; Saputra et al., 2018). Dengan menggunakan media video pembelajaran, dapat merangsang pikiran, perasaan, dan kemauan siswa untuk belajar. Selain itu, media video pembelajaran tidak dibatasi oleh ruang dan waktu, karena media video dapat menampilkan masa lalu dan masa sekarang, pesan yang berukuran besar atau kecil, memiliki kecepatan tinggi atau rendah, dan berwarna atau tidak berwarna. Dengan mengkombinasikan model pembelajaran kooperatif tipe jigsaw dengan media video pembelajaran pada muatan pelajaran IPS, diharapkan dapat menarik perhatian siswa dalam proses pembelajaran sehingga dapat meningkatkan hasil belajar siswa.

Beberapa penelitian yang relevan dengan penelitian ini seperti penelitian yang dilakukan oleh (Permana \& Wardani, 2021) yang menemukan bahwa model kooperatif tipe jigsaw berbantuan video pada siswa kelas VI meningkatkan hasil belajar siswa. Kemudian penelitian lain juga menemukan bahwa model pembelajaran kooperatif tipe jigsaw bebantuan media audio visual berpengaruh signifikan terhadap kompetensi pengetahuan IPS siswa kelas IV SD (Anggreni, 2017). Penerapan metode jigsaw dapat meningkatkan hasil belajar IPA pada siswa kelas IV SD (Sri Astiti \& Murda, 2017). Tujuan penelitian ini untuk menganalisis model pembelajaran kooperatif tipe Jigsaw berbantuan media video untuk meningkatkan hasil belajar siswa kelas IV sekolah dasar.

\section{MATERIALS AND METHODS}

Berdasarkan karekterikstik masalah yang diteliti, penelitian ini dapat dikla-sifikasikan ke dalam penelitian tindakan kelas (PTK) karena penelitian ini digunakan untuk memecahkan masalah pembelajaran di kelas. Penelitian ini juga termasuk penelitian deskriptif karena menggambarkan penerapan suatu pembelajaran untuk meningkatkan hasil belajar. Subjek 
dalam penelitian ini adalah siswa kelas IV A di SDN 4 Kampung Baru Tahun Ajaran 2017/2018 yang berjumlah 26 orang siswa. Objek penelitian ini adalah hasil belajar kognitif IPS siswa kelas IV A di SDN 4 Kampung Baru Tahun Ajaran 2017/2018. Alur pelaksanaan PTK dapat dilihat pada Gambar 1.

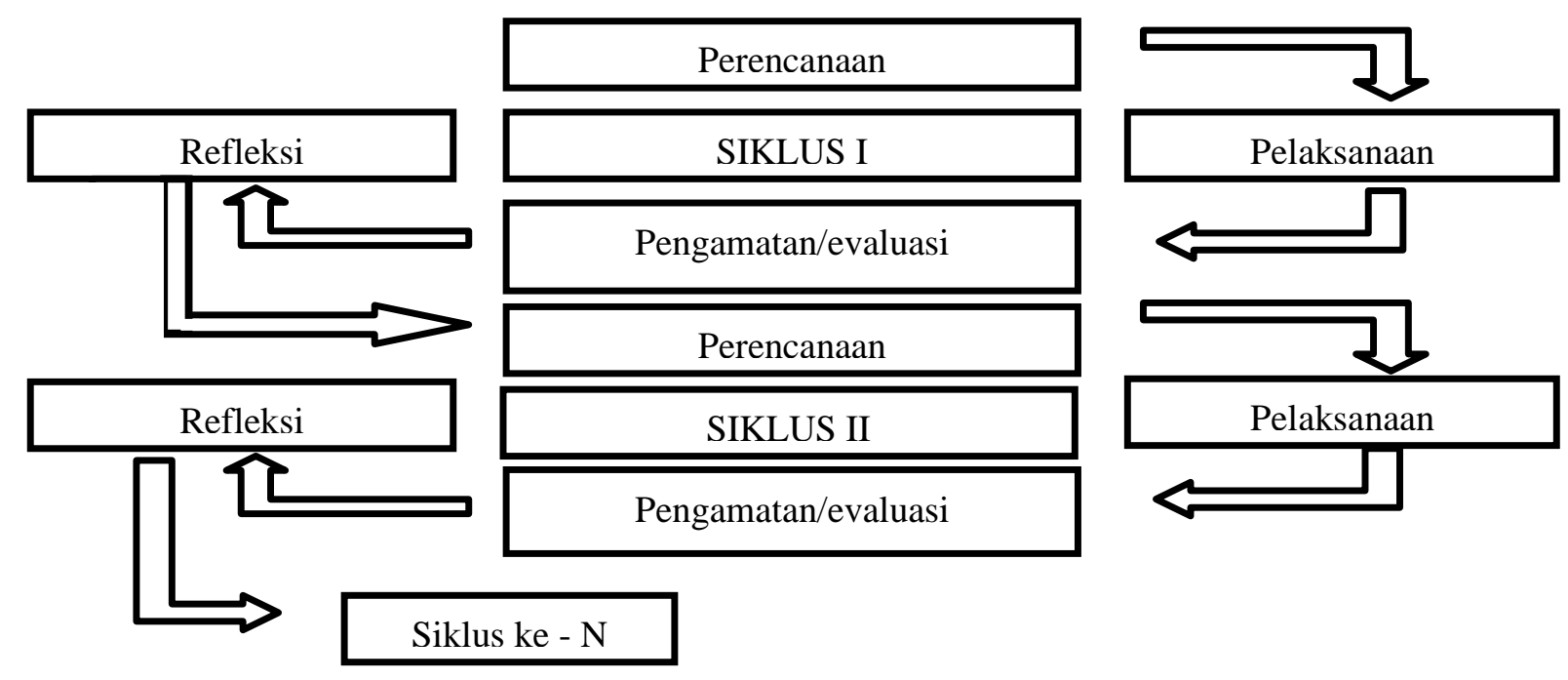

Gambar 1. Siklus PTK

Penelitian ini dilakukan dengan tahapan-tahapan diantaranya perencanaan, pelaksanaan, pengamatan dan evaluasi, dan refleksi. Pada akhir siklus ini, dilakukan refleksi untuk merenungkan dan mengkaji hasil tindakan pada siklus I mengenai hasil belajar IPS. Peneliti bersama guru melakukan refleksi yang berpedoman kepada hasil evaluasi dan observasi, serta kendala-kendala yang diperoleh selama pelaksanaan kegiatan siklus I. Dengan hasil refleksi ini, peneliti bersama guru mencoba merumuskan tindakan baru sebagai penyempurnaan terhadap tindakan yang telah dilakukan. Alternatif tindakan baru ini akan ditetapkan menjadi tindakan baru pada rencana tindakan dalam penelitian tindakan kelas siklus berikutnya. Data yang dikumpulkan dalam penelitian ini adalah data tentang hasil belajar IPS siswa. Untuk memeroleh data tersebut, digunakan metode tes berbentuk tes tulis yang digunakan untuk mengetahui hasil belajar IPS siswa. Instrument yang digunakan berupa tes berbentuk pilihan ganda dengan menggunakan empat pilihan, yaitu a, b, c, dan d serta tes berbentuk isian singkat. Tes dalam penelitian ini dibuat berdasarkan kisi-kisi yang telah dibuat sebelumnya. Data penelitian yang telah berkumpul selanjutnya dianalisis. Dalam menganalisis data ini digunakan metode analisis statistik deskriptif dan analisis deskriptif kuantitatif.

\section{RESULTS AND DISCUSSION}

Deskripsi data hasil belajar IPS siswa siklus I dan Siklus II memaparkan mengenai jumlah siswa, mean, skor terendah, skor tertinggi, jumlah siswa yang tuntas, jumlah siswa yang tidak tuntas, dan ketuntasan klasikal. Hasil perhitungan hasil belajar IPS siswa pada siklus I dapat dilihat pada Tabel 1.

Tabel 1. Data hasil Belajar IPS Siswa pada Siklus I

\begin{tabular}{ccc}
\hline No & Aspek & Keterangan Nilai \\
\hline 1 & Jumlah Siswa & 26 \\
2 & Mean & 80,77 \\
\hline
\end{tabular}




\begin{tabular}{ccc}
\hline No & Aspek & Keterangan Nilai \\
\hline 3 & Skor Terendah & 65 \\
4 & Skor Tertinggi & 100 \\
5 & Jumlah Siswa Tidak Tuntas & 11 \\
6 & Jumlah Siswa Tuntas & 15 \\
7 & Ketuntasan Klasikal & $58 \%$ \\
\hline
\end{tabular}

Berdasarkan Tabel 1. jumlah siswa adalah 26 orang dan seluruhnya mengikuti tes. Jumlah nilai yang diperoleh dari keseluruhan siswa adalah 2100 sehingga rata-rata nilai siswa adalah 80.77 memiliki kriteria tinggi. Nilai terendah yang diperoleh siswa adalah 65 dan nilai tertinggi adalah 100. Siswa yang tuntas 15 siswa dan yang tidak tuntas ada 11 siswa dengan persentase ketuntasan klasikal mencapai 58\%. Peningkatan masih dalam kategori rendah yaitu 0,16 (predikat rendah) sehingga masih perlu adanya peningkatan yang akan dilaksanakan pada siklus II. Hasil belajar IPS pada siklus II dapat dilihat pada Tabel 2.

Tabel 2. Data Hasil Belajar IPS Siswa pada Siklus II

\begin{tabular}{ccc}
\hline No & Aspek & Keterangan Nilai \\
\hline 1 & Jumlah Siswa & 26 \\
2 & Mean & 86,37 \\
3 & Skor Terendah & 66 \\
4 & Skor Tertinggi & 100 \\
5 & Jumlah Siswa Tidak Tuntas & 19 \\
6 & Jumlah Siswa Tuntas & 7 \\
7 & Ketuntasan Klasikal & $73 \%$ \\
\hline
\end{tabular}

Berdasarkan Tabel 2. jumlah siswa adalah 26 orang dan seluruhnya mengikuti tes. Jumlah nilai yang diperoleh dari keseluruhan siswa adalah 2246 sehingga rata-rata nilai siswa adalah 86,37 memiliki kriteria tinggi. Nilai terendah yang diperoleh siswa adalah 66 dan nilai tertinggi adalah 100. Siswa yang tuntas 19 siswa dan yang tidak tuntas ada 7 siswa dengan persentase ketuntasan klasikal mencapai $73 \%$. Hasil yang diperoleh pada siklus II tersebut telah mencapai indikator keberhasilan untuk hasil belajar siswa yang telah ditetapkan dalam penelitian ini yaitu peningkatan mencapai predikat minimal sedang dengan kriteria 0,30-0,69. Peningkatan dalam kategori sedang yaitu 0,46 . Penelitian yang sudah dilakukan pada siklus II mengenai hasil belajar IPS siswa telah mengalami peningkatan serta telah berlangsung dengan baik. Tanggapan siswa terhadap pembelajaran yang telah dilaksanakan sangat baik. Berdasarkan penjabaran di atas, indikator keberhasilan penelitian yang meliputi hasil belajar IPS siswa telah tercapai. Sehingga penelitian ini dikatakan berhasil dan penelitiaan ini hanya dilaksanakan dalam 2 siklus.

Penelitian Tidakan Kelas (PTK) ini dilaksanakan sebagai upaya untuk meningkatkan hasil belajar siswa dengan menggunakan model pembelajaran kooperatif tipe jigsaw. Prosedur penelitian yang digunakan adalah prosedur penelitian tindakan kelas yang dilaksanakan dalam bentuk siklus. Dalam penelitian ini digunakan dua siklus yang masingmasing siklus terdiri dari dua kali pertemuan dan setiap siklus dilaksanakan sesuai dengan skenario yang telah dibuat dan memuat empat tahap kegiatan yaitu tahap perencanaan, tahap pelaksanaan tindakan, tahap observasi dan evaluasi yang dilanjutkan dengan tahap refleksi.

Hasil penelitian ini menunjukkan bahwa penerapan model pembelajaran kooperatif tipe Jigsaw yang dalam pengaplikasiannya dibantu dengan media video pembelajaran, dapat meningkatkan hasil belajar IPS siswa kelas IVA SDN 4 Kampung Baru dari siklus I ke siklus 
II. Hasil belajar IPS yang diperoleh pada siklus I belum memenuhi kriteria keberhasilan yang telah ditentukan. Sedangkan, hasil belajar IPS yang diperoleh pada siklus II, menunjukkan persentase rata-rata hasil belajar memenuhi kriteria keberhasilan yang telah ditentukan.

Berdasarkan hasil analisis data pelaksanaan tindakan pada siklus I menunjukkan bahwa peningkatan hasil belajar siswa belum mencapai indikator keberhasilan yang diinginkan. Terdapat kekurangan yang diperoleh dari hasil refleksi dalam proses pembelajaran pada siklus pertama, seperti siswa kurang serius dan sering membuat gaduh terutama ketika pembentukan kelompok ahli dan siswa yang kemampuannya kurang sulit mengerjakan tugas yang diberikan. Perlu adanya perbaikan pada kekurangan tersebut. Terlepas dari hal itu, proses pembelajaran melalui penerapan model pembelajaran kooperatif tipe jigsaw yang dibantu dengan pengunaan madia video pembelajaran sudah menunjukkan adanya kelebihan yang terlihat dari beberapa hal diantaranya 1) perhatian siswa terpusat pada materi yang dipelajari, 2) semangat dan antusiasme siswa yang tinggi serta tertarik mengikuti pelajaran, 3) komunikasi antar siswa sudah mulai terlihat dalam kerja kelompok, 4) siswa yang memiliki kemampuan lebih mau membantu temannya yang masih kurang.

Berdasarkan keterangan di atas mengenai adanya kekurangan yang perlu diperbaiki serta kelebihan yang perlu dipertahankan atau ditingkatkan, maka tindakan perbaikan yang dilaksanakan pada siklus II antara lain 1) guru lebih mengawasi siswa agar lebih tertib, serius dalam belajar, tidak membuat gaduh, serta selalu memperhatikan dan menyimak temannya yang sedang bertanya atau mempresentasikan hasil kerjanya, 2) guru lebih memotivasi siswa dalam proses pembelajaran dengan memberikan reward secara visual atau nonvisual agar siswa berani mengajukan pertanyaan kepada guru maupun temannya serta berdiskusi dengan temannya, 3) guru hendaknya meminta siswa untuk mempelajari materi yang sudah dibahas agar tidak lupa serta memberikan pesan moral kepada siswa terkait materi pembelajaran.

Adapun hasil pembelajaran pada siklus II setelah melaksanakan tindakan perbaikan mengalami peningkatan dan terlaksana dengan baik. Hal ini terlihat dari peningkatan hasil hasil belajar siswa, nilai rata-rata pada siklus I sejumlah 80.77 , persentase ketuntasan klasikal $58 \%$ dengan predikat peningkatan rendah yaitu 0,16 meningkat menjadi rata-rata 86,37 berkriteria tinggi, ketuntasan klasikal mencapai $73 \%$ dengan predikat peningkatan sedang yaitu 0,46 pada siklus II.

Berdasarkan data di atas, terdapat peningkatan hasil belajar IPS dari siklus I ke siklus II. Peningkatan hasil belajar IPS disebabkan oleh beberapa faktor. Pertama, penerapan model pembelajaran kooperatif tipe Jigsaw siswa diajak belajar berdiskusi dengan baik dan bertanggungjawab pada pekerjaan yang diberikan kepada siswa. Dengan penerapan model pembelajaran tersebut, siswa berusaha mempelajari materi agar dapat menyelesaikan tugas yang menjadi tanggungjawabnya dengan baik. Penerapan model ini juga mendorong siswa aktif berbagi informasi agar dapat mencapai prestasi kelompok yang maksimal. Pembelajaran kooperatif tipe jigsaw merupakan salah satu tipe pembelajaran kooperatif yang mendorong siswa aktif dan saling membantu dalam penguasaan materi pelajaran untuk mencapai prestasi yang maksimal. Dengan demikian, siswa berusa sebaik mungkin agar dapat menampilkan presentasi kelompok yang baik di depan teman-temannya di kelompok lain (Andayani et al., 2019; Wahyuni et al., 2021).

Kedua, siswa mengamati video pembelajaran yang berkaitan dengan materi pelajaran. Siswa dapat mengamati video pembelajaran dengan baik. Melalui kegiatan pengamatan siswa dapat mengkonstruksi pengetahuannya sendiri. Siswa dapat belajar dari mengamati video pembelajaran yang terkait dengan materi pelajaran. Kegiatan mengamati video pembelajaran, dapat memudahkan siswa mengumpulkan informasi terkait dengan materi yang akan dipelajari, sehingga dapat membantu siswa belajar dengan baik (Gading \& Kharisma, 2017; Pramana \& Suarjana, 2018; Sulfemi \& Mayasari, 2019). Media video pembelajaran dapat membantu siswa memperjelas suatu konsep dan dapat memahami materi pelajaran, sehingga 
dapat meningkatkan hasil belajar. Suatu konsep yang abstrak atau tidak bisa dihadirkan ke kelas secara langsung, dapat diatasi melalui sajian media video pembelajaran sehingga konsep yang diterima siswa menjadi jelas dan mudah dipahami siswa.

Ketiga, peningkatan hasil belajar IPS disebabkan oleh aktivitas belajar siswa. Siswa melakukan berbagai aktivitas belajar selama proses pembelajaran berlangsung. Siswa melakukan aktivitas belajar, seperti membaca buku, memperhatikan penjelasan guru, mendengarkan persentasi kelompok lain, tanya-jawab, mengemukakan pendapat, memberikan saran, mengamati media video pembelajaran, dan mengikuti setiap tahap proses pembelajaran. Siswa dapat melakukan aktivitas belajar dengan baik, sehingga dapat meningkatkan hasil belajar IPS. Aktivitas belajar yang dilakukan siswa dapat meningkatkan pemahaman materi yang dipelajari sehingga hasil belajar siswa meningkat. Hal ini sesuai Aktivitas belajar dapat memberikan nilai tambah bagi peserta didik untuk menumbuh kembangkan pemahaman terhadap materi yang dipelajari (Jannah \& Mudjiran, 2019; Marlina, Fadilah, 2019; Ningsih et al., 2019; Sariayu \& Miaz, 2020).

Beberapa penelitian yang relevan dengan penelitian ini seperti penelitian yang dilakukan oleh (Permana \& Wardani, 2021) yang menemukan bahwa model kooperatif tipe jigsaw berbantuan video pada siswa kelas VI meningkatkan hasil belajar siswa. Kemudian penelitian lain juga menemukan bahwa model pembelajaran kooperatif tipe jigsaw bebantuan media audio visual berpengaruh signifikan terhadap kompetensi pengetahuan IPS siswa kelas IV SD (Anggreni, 2017). Penerapan metode jigsaw dapat meningkatkan hasil belajar IPA pada siswa kelas IV SD (Sri Astiti \& Murda, 2017).

\section{CONCLUSION}

Pembelajaran dengan penerapan model pembelajaran kooperatif tipe Jigsaw berbantuan media video terbukti dapat meningkatkan hasil belajar IPS siswa. Hal ini dibuktikan dengan adanya peningkatan hasil belajar IPS secara klasikal yang dilakukan dari siklus I ke siklus II. Guru hendaknya menerapkan model pembelajaran ini sebagai salah satu alternatif pembelajaran dalam upaya meningkatkan hasil belajar siswa.

\section{REFERENCES}

Adiwiguna, I. W., Wiarta, I. W., \& Abadi, I. B. G. S. (2016). Model Pembelajaran Role Playing Berbasis Pendekatan Saintifik Berpengaruh terhadap Penguasaan Kompetensi Pengetahuan IPS. Mimbar PGSD, 4(1). http://dx.doi.org/10.23887/jjpgsd.v4i1.7253.

Andayani, N. P. R., Asri, I. G. A. A. S., \& Suniasih, N. W. (2019). Pengaruh Model Pembelajaran Jigsaw Berbasis Penilaian Portofolio terhadap Kompetensi Pengetahuan PKn. Jurnal Pedaagogi dan Pembelajaran, 2(3). http://dx.doi.org/10.23887/jp2.v2i3.19280.

Anggreni, L. P. D. K. (2017). Pengaruh Model Pembelajaran Kooperatif Tipe Jigsaw Berbantuan Media Audio Visual Terhadap Penguasaan Kompetensi Pengetahuan IPS Siswa Kelas IV SD Gugus 1 Dalung. Mimbar PGSD, 5(2). http://dx.doi.org/10.23887/jjpgsd.v5i2.11020.

Arikunto, S. (2013). Dasar-Dasar Evaluasi Pendidikan. Bumi Aksara.

Darihastining, S., Aini, S. N., Maisaroh, S., \& Mayasari, D. (2020). Penggunaan Media Audio Visual Berbasis Kearifan Budaya Lokal pada Anak Usia Dini. Jurnal Obsesi: Jurnal Pendidikan Anak Usia Dini, 5(2), 1594-1602. https://doi.org/10.31004/obsesi.v5i2.923.

Effendi-Hasibuan, M. H., Fuldiaratman, F., Dewi, F., Sulistyo, U., \& Hindarti, S. (2020). Jigsaw learning strategy in a diverse science-classroom setting: Feasibility, challenges, and adjustment. Cakrawala Pendidikan, 39(3), 733-745. https://doi.org/10.21831/cp.v39i3.30634.

Gading, I. K., \& Kharisma, K. D. (2017). Pengaruh Model Pembelajaran Kooperatif Tipe Make A Match Berbantuan Media Powerpoint Terhadap Hasil Belajar IPA. International Journal of Elementary Education, 1(2). http://dx.doi.org/10.23887/ijee.v1i2.11608. 
Jannah, N. H., \& Mudjiran, M. (2019). Pengaruh Model Pembelajaran Kooperatif Tipe Think Pair Share Terhadap Aktivitas dan Hasil Belajar Peserta Didik. Jurnal Basicedu, 3(4), 2125-2129. https://doi.org/10.33627/ge.v2i2.23.

Marlina, Fadilah, M. (2019). Dasar-Dasar Evaluasi Pendidikan. Bumi Aksara. Jurnal Basicedu, 3(4), 1047-1054. https://doi.org/10.31004/basicedu.v3i4.209.

Maulida, I., Dibia, I. K., \& Astawan, I. G. (2020). The Development of Social Attitude Assessment Instrument and Social Studies Learning Outcomes Grade IV on Theme of Indahnya Keragaman di Negeriku. Indonesian Journal Of Educational Research and Review, 3(1), 12. https://doi.org/10.23887/ijerr.v3i2.25823.

Meiyani, K. S., Putra, M., \& Suadnyana, I. N. (2017). Pengaruh Model Quantum Teaching Melalui Karyawisata Terhadap Penguasaan Kompetensi Pengetahuan IPS Siswa Kelas V. MIMBAR PGSD Undiksha, 5(2). http://dx.doi.org/10.23887/jjpgsd.v5i2.10836.

Ningsih, S. R., Miaz, Y., \& Zikri, A. (2019). Model Discovery Learning untuk Meningkatkan Aktivitas dan Hasil Belajar Tematik Terpadu di Sekolah Dasar. Jurnal Basicedu, 3(4), 10651072. https://doi.org/https://doi.org/10.31004/basicedu.v3i4.203.

Permana, Y., \& Wardani, D. S. (2021). Pembelajaran Mengenai Sistem Penanggalan Kalender Masehi dan Hijriah untuk Mengukur Hasil Belajar Siswa dengan Model Cooperative Tipe Jigsaw Berbantuan Video pada Siswa Kelas VI SD. Collase (Creative of Learning Students Elementary Education), 04(03), 428-436. https://www.journal.ikipsiliwangi.ac.id/index.php/collase/article/view/5335.

Ponza, P. J. R., Jampel, I. N., \& Sudarma, I. K. (2018). Pengembangan Media Video Animasi pada Pembelajaran Siswa Kelas IV di Sekolah Dasar. Jurnal Edutech Undiksha, 6(1), 9-19. http://dx.doi.org/10.23887/jeu.v6i1.20257.

Pramana, I. P. Y., \& Suarjana, I. M. (2018). Pengaruh Model Pembelajaran Time Token Berbantuan Media Video terhadap Hasil Belajar IPA Kelas V SD. Journal of Education Technology, 4(2), 137-144. http://dx.doi.org/10.23887/jet.v2i4.16425.

Putra, M., Darsana, I. W., \& Darmayanti, N. K. A. M. (2017). Pengaruh Model Pembelajaran Numbered Head Together Berbasis Reinforcement terhadap Penguasaan Kompetensi Pengetahuan IPS Siswa Kelas V. International Journal of Elementary Education, 1(2), 145152. http://dx.doi.org/10.23887/ijee.v1i2.11607.

Putri, R. ayu S., Putra, I. K. A., \& Abadi, I. B. G. S. (2016). Penerapan Pembelajaran Kooperatif Tipe Jigsaw dalam Pendekatan Saintifik dapat Meningkatkan Hasil Belajar Bahasa Indonesia. EJournal PGSD Universitas Pendidikan Ganesha, 4(1). http://dx.doi.org/10.23887/jjpgsd.v4i1.7240.

Risky, S. M. (2019). Analisis Penggunaan Media Video pada Mata Pelajaran IPA di Sekolah Dasar. Sekolah Dasar: Kajian Teori Dan Praktik Pendidikan, 28(2), 73-79. https://doi.org/10.17977/um009v28i22019p073.

Rusmawan, R. (2013). Faktor yang memengaruhi kesulitan belajar IPS siswa sekolah dasar. Jurnal Cakrawala Pendidikan, 2. https://journal.uny.ac.id/index.php/cp/article/view/1487/pdf.

Saputra, I. G. N. H., Joyoatmojo, S., \& Harini, H. (2018). The implementation of project-based learning model and audio media Visual can increase students' activities. International Journal of Multicultural and Multireligious Understanding, 5(4), 166-174. https://doi.org/10.18415/ijmmu.v5i4.224.

Sariayu, M. R., \& Miaz, Y. (2020). Peningkatan Aktivitas Belajar Siswa Melalui Model Think Pair Share di Sekolah Dasar. Jurnal Basicedu, 4(2), 295-305. https://doi.org/10.31004/basicedu.v4i2.337.

Sawitri, N. N. R., Suniasih, N. W., \& Sujana, I. W. (2018). Pengaruh Model Pembelajaran CIRC Berbasis Karakter terhadap Kompetensi Pengetahuan IPS Siswa. Jurnal Mimbar Ilmu, 23(2). http://dx.doi.org/10.23887/mi.v23i2.16420.

Sri Astiti, D. K., \& Murda, I. N. (2017). Penerapan Metode Pembelajaran Jigsaw Sebagai Upaya Meningkatkan Hasil Belajar IPA Pada Siswa Kelas IV SD. Journal of Education Action Research, 1(2), 94. https://doi.org/10.23887/jear.v1i2.12043.

Sulfemi, W. B. (2019). Model Pembelajaran Kooperatif Mind Mapping Berbantu Audio Visual Dalam Meningkatkan Minat, Motivasi Dan Hasil Belajar IPS. Jurnal PIPSI (Jurnal Pendidikan IPS Indonesia), 4(1), 13. https://doi.org/10.26737/jpipsi.v4i1.1204. 
Sulfemi, W. B., \& Mayasari, N. (2019). Peranan Model Pembelajaran Value Clarificationtechnique Berbantuan Media Audio Visual Untuk Meningkatkan Hasil Belajar IPS. Jurnal Pendidikan, 20(1), 53. https://doi.org/10.33830/jp.v20i1.772.2019.

Wahyuni, C., Sari, P., \& Indarini, E. (2021). Meta Analisis Komparasi Efektivitas Model Pembelajaran Jigsaw dan Two Stay Two Stray (TSTS) Ditinjau dari Hasil Belajar Pembelajaran Tematik Siswa SD. Jurnal Pedaagogi dan Pembelajaran, 4(1), 101-110. http://dx.doi.org/10.23887/jp2.v4i1.33251.

Widiana, I. N. A., Murda, I. N., \& Margunayasa, I. G. (2015). Pengaruh Model Pembelajaran Kooperatif Tipe Jigsaw 1 Dengan Bantuan Media Konkret Terhadap Hasil Belajar IPA Kelas V di SD Gugus XIV, kecamatana Buleleng tahun pelajaran 2014/2015. Mimbar PGSD Universitas Pendidikan Ganesha, 3(1). http://dx.doi.org/10.23887/jjpgsd.v3i1.5675.

Zubaidah, S., Corebima, A. D., Mahanal, S., \& Mistianah. (2018). Revealing the relationship between reading interest and critical thinking skills through remap GI and remap jigsaw. International Journal of Instruction, 11(2), 41-56. https://doi.org/10.12973/iji.2018.1124a. 